\title{
Sinematografik Bir Öğe Olarak Türk Polisiye Filmlerinde Aydınlatma Tasarımı: "Av Mevsimi" Filmi Örneğinde Bir Değerlendirme
}

DOI: $10.26466 /$ opus.678777

*

\author{
Onur Erkan* - Murat Aytaș** \\ * Doktora Öğrencisi, Hacı Bayram Veli Üniversitesi, Lisansüstü Eğitim Enstitüsü, Ankara,Türkiye \\ E-Posta: erkanonur00@gmail.com \\ ORCID: $\quad$ 0000-0002-6937-2860 \\ ** Dr, Öğr. Üyesi Selçuk Üniversitesi, İletişim Fakültesi, Selçuklu / Konya/ Türkiye \\ E-Posta: murataytas@hotmail.com \\ ORCID: $\quad$ 0000-0003-2744-0519
}

\begin{abstract}
Öz
Polisiye türünün, sinemadaki ilk zamanlarında edebi hikayelerden uyarlama öykülerle temsil edildiği görülürken, 1970'li yillardan sonra özgün hikaye ve senaryolarla izleyici karşısına çıtıı̆ğ görülür. Polisiye türünün, kendine has karakteristik içerik ve sinematografik biçimle sinema sanatı içerisinde temsil edilmesiyle, başlı başına bir tür olarak ele alınmaya başlandığını söylemek mümkündür. Türk sinemasındaki ilk örnekleri 1940'l y yllarla birlikte başlamakla birlikte 1970 ve 80'li yıllarda polisiye türüne ait pek çok başarıll eser beyaz perdeye aktarılmıştır. 2000'li yıllara gelindiğinde ise Türk sineması polisiye türündeki Polis, Pars Kiraz Operasyonu, Sis ve Gece, Çakal, Başka Semtin Çocukları, Ejder Kapan ve Av Mevsimi gibi filmlerin ardı ardına vizyona girişiyle adeta bu türün yükselişine sahne olmuştur. Yavuz Turgul'un 2010 yılında yönetmiş olduğu ve oyuncu kadrosunda Şener Şen, Çetin Tekindor ve Cem Yllmaz gibi isimlerin yer aldığı Av Mevsimi filmi Türk polisiye sineması içerisinde çekilen yetkin eserlerden biridir. Türk polisiye filmleri arasından seçilen bu örnek üzerinden, psikolojik, estetik ve dramatik aydınlatmanın film biçemine olan katkısının analiz edilmesi araştırmanın temel amacıdır. Film türlerine göre çeşitlere ayırabileceğimiz aydınlatma teknikleri, sinematografik açıdan polisiye film türüne özgü bir takım farklılıklar gösterir. Bu araştırmanın söz konusu bu farklllıklar ortaya koyması açısından literatüre katkı sağlayacağı düşünülmektedir.
\end{abstract}

Anahtar Kelimeler: Türk sineması, Polisiye film, Av mevsimi 


\title{
Lighting Design in Turkish Detective Films as a Cinematographic Element: An Evaluation on the Example of "Av Mevsimi" Movie
}

\begin{abstract}
While it is seen that the crime type was represented by adaptive stories from literary stories in the early days of the cinema, it is seen that it appeared before the audience with original stories and scenarios after 1970s. It is possible to say that the crime genre has begun to be treated as a genre by itself, by representing it in cinema art with its unique characteristic content and cinematographic form. Although the first examples of Turkish cinema started with the 1940s, many successful works of the crime genre were transferred to the big screen in the 1970s and 80s. In the 2000s, Turkish cinema was the scene of the rise of this genre with the success of films such as Polis, Pars Kiraz Operasyonu, Sis ve Gece, Çakal, Başka Semtin Çocukları, Ejder Kapanı and Av Mevsimi. The Av Mevsimi movie, directed by Yavuz Turgul in 2010 and starring Şener Şen, Çetin Tekindor and Cem Yilmaz, is one of the competent works shot in Turkish detective cinema. The main purpose of the research is to analyze the contribution of psychological, aesthetic and dramatic lighting to the film style through this example selected from Turkish detective films. The lighting techniques, which we can divide according to the types of films, show a number of cinematographic differences specific to the type of crime film. It is thought that this research will contribute to the literature in terms of revealing these differences.
\end{abstract}

Keywords: Turkish cinema, Detective film, Av mevsimi 


\section{Giriş}

Kavramsal ve olgusal olarak suçun tarihi insanlığın tarihi ile aynı yaştadır. İlk örneklerini dinsel ve mitolojik metinlerde gördüğümüz suç ve suçluya dair çoğunlukla bireysel öyküler tarih boyunca tüm anlatılarda yer alır. İnsanların nüfus artışıyla birlikte büyük şehirlerde yaşamaya başlamalarıyla suç kavramına bakış ise bireysellikten toplumsallığa doğru kaymıştır. Bu nedenden dolayı bir arada yaşayan insanlar arasındaki anlaşmazlıkları ortadan kaldırmak ve onların güvenliğini sağlamak amacıyla adli ve güvenlik birimlerinin ortaya çıkışı da bu yıllarda görülür. Suç ve suçlunun toplumsal alandaki karşılığı ve kavramsallaştırılması kendini yalnızca hukuk sisteminde değil sanatta da bulur. Mitolojiden, edebi öykülere oradan da sinemaya uzanan metinlerarası bir anlatı formu olarak kendini sürekli yeniler ve üretir. Suça dair öykülerin içinde barındırdığı merak unsuru ve katharsis duygusu izleyicinin bu türü tercih etmesinde önemlidir. Polisiye olarak ifade edebileceğimiz bu türün sinemaya perdesine aktarılması ise sinematografik olarak biçime ve içeriğe dair bir takım kodlarla gerçekleşir. Film biçeminin en önemli öğelerinden biri olan 1 şık ve aydınlatma dramatik yapının kurulmasında oldukça önemli işlevler kazanur.

Dramatik yapının sinematografik olarak kurulması ya da diğer deyişle sinema sanatı içinde bir görüntünün oluşması, ışı̆̆ın varlığıyla mümkündür. Sinema sanatının estetik tarafını oluşturan film görüntüsü ışı̆̆ın disipline edilmesiyle varolur. Işık salt nesnelerin aydınlatması amacıyla değil dramatik yapının kuruluşunda anlamın inşa edilmesine de hizmet eder. Bu noktada aydınlatma teknikleri, yalnızca nesneleri aydınlatmak için değil onlara çeşitli anlamlar yüklemek ya da var olan anlatımı desteklemek amacıyla da tercih edilirler. Sinema aydınlatmayla ilgili tekniklerinin bir çoğunu resim sanatından devralmıştır. Caravaggio, Rembrant gibi pek çok ressamın ışığı görme ve kullanma biçimi sinemada anlam ve anlatımı desteklemek amacıyla sıklıkla görüntü yönetmenleri tarafından tercih edilir. Polisiye türünün görselleştirilmesine dair genel formulizasyonu ve anlatımının desteklenmesi, aydınlatma teknikleriyle gerçekleştirilir. Polisiye türü içerisinde sıkça karşılaşılan gizem, gerilim, tehlike gibi unsurlar aydınlatma teknikleri aracılığıyla anlatım açısından daha güçlü ifade edilebilme imkanı bulur.

Polisiye film türünün karakteristik özellikleriyle sinematografik bir öğe olan aydınlatma tekniklerinin birlikte ele alınması anlamın bu tür içerisinde 
kurulması açısından önemlidir. Araştırmada 2000 sonrası Türk sinemasında polisiye film türünde sıklıkla kullanılan kamera açıları ve bu kamera açılarına bağlı tasarlanan aydınlatma tekniklerinin dramatik yapıyla olan ilişkileri, yönetmenliğini Yavuz Turgul'un yaptı̆̆ 2010 yapımı Av Mevsimi filmi örneği üzerinden incelenecektir. Resim sanatındaki eserleri inceleme amaciyla tercih edilen biçimsel analiz yönteminin, sinema sanatında iki boyutlu düzlem üzerine yansitılan görüntüleri irdeleme amaciyla da tercih edildiği sıklıkla görülür. Bu çalışmada örnek olarak seçilen Av Mevsimi filmi, biçimsel analiz yöntemiyle çözümlenecektir. Türk sinemasına yönelik olarak aydınlatma ve ışık kullanımı özelinde yapılmış çok fazla çalışma olmadığı göz önünde bulundurulduğunda konuyla ilgili yapılan her araştırmanın Türk sinemasına katkı sağlayacağı düşünülmektedir.

\section{Edebiyattan Sinemaya Sanatsal Bir Anlatı Türü Olarak Polisiye}

18. yüzyılda sanayi devrimiyle birlikte nüfusun büyük şehirlerde toplanması büyük değişimlere yol açmıştır. Sanayi şehirlerinin giderek büyüyen nüfusları bu yapıya uyum sağlayamayan ya da var olma mücadelesine katılan insanlar açısından sosyolojik olarak şehirlerdeki suç oranlarının artmasına neden olmuştur. Şehirlerin karmaşık yapısı bireyselliği daha fazla ön plana çıkarmakta ve gelir düzeyleri farklı olan insanlar arasında bir rekabet ortamı da oluşmasına sebep olmaktaydı. Büyüyen şehirlerde artışa uğrayan suç oranları, dönemin sanatçıları tarafından üretilen sanat eserlerinde sıklıkla işlenir hale gelmiştir. 1799 yılında Paris' in uzak bölgelerinde soyguna dayalı vahşi bir suç işlenmiş ve 'bu tüyler ürperten sahne bir gravürde tasvir edilmiştir' (Emsley, Makov, 2006, s.39). Gravürde; arka taraftaki demir parmaklıklara sıkışan bir kol ve kesilen baştan fişkıran kanlar, ön taraftaysa üç kişinin caddede koştuğu görünür. 19. yüzyılın önemli sanatçılarından biri olan İspanyol ressam Francisco de Goya, 1814 yılında ürettiği eserinde İspanya'nın işgal edilmesi sonucunda ayaklanan İspanyolların, Napolyon ordusu tarafından kurşuna dizilmesini betimler. Her sanatçı gibi Goya'da bu yapıt aracıllğıyla çağına tanıklık eder. (Ötgün, 2008, s.93). Suç ve suça dayalı olaylar dizisini, resim sanatı dışında edebi sanat eserlerinde de görmek mümkündür.

Polisiye anlatısının tür bağlamında ele alındığı ilk eserler, edebi metinler olarak dikkat çeker. Polisiye edebiyatı olarak isimlendirilen bu türün ilk örneklerine ise batı edebiyatında karşılaşılır. Polisiye edebiyat ilk zamanlarında 
gizem edebiyatı (ing. mystery) olarak isimlendirilirken, daha sonraları şüphe-gerilim (ing. suspense) ve suç (ing. crime-criminal) gibi isimlerle anılmaya başlanmıştır (Holat, 2015, s.67).

Suç ve suçlu bireyin, suça dayalı olayların varlığı, polisiye roman türünün ana konusunu oluşturur. İnsanlık tarihi boyunca çeşitli edebi türler ve dini kitaplar içerisinde de bu unsurlara sıkça yer verilmiştir. Polisiyenin tür olarak ele alınması, bahsi geçen çeşitli edebi türler ve dini kitaplardan farklı olarak değerlendirilebilmesi için belirli özellikleri barındırması gerekir. Bazı kaynaklara göreyse bu farklılıklar polis, dedektif, suç gibi kavramların ortaya çıkmasıyla sağlanır. Polisiye roman türü konularını bu kavramlar üzerinden formülize eder. Genel itibariyle polisiye romanlarda, işlenen bir suç ve bu suçu işleyen bireylerle birlikte suçun nasıl ve kim tarafından işlendiğini ortaya çkarmayı hedefleyen polis ve dedektifler yer alır. Polisiye romanin ana kurgusu genellikle karmaşık ve çözülmesi zor olan bir suçla başlar. İşlenen suçun kim tarafından gerçekleştirildiği ve nasıl işlendiği araştırılırken bulunan ipuçlarıyla birlikte suçsuz bir şüpheli belirlenir. Polis teşkilatına bağlı ekiplerin dikkatsizliği ve umursamazlığı yüzünden soruşturma zarar görür ve soruşturmaya zeki, uyanık, becerikli bir dedektif dâhil olur. Sağlam deliller üzerinde durularak güvenilir olmayan gösterge ve ipuçları yok edilir. Bu araştırmalar sonucunda ise suçun beklenmeyen bir kişi tarafından işlendiği ortaya çıkar. Polisiye romanın ana kurgusu içerisinde bu bilgiler doğrultusunda üç temel unsurdan bahsetmek mümkün olacaktır. Polisiye romanlardaki bu üç temel unsur ise suç, suçlu ve çözüm olarak sıralanabilir. (Çetin, 2009, s.225).

19. yy'da endüstrileşmeyle birlikte şehirleşmenin en yoğun yaşandığı ülkelerden birisinin Amerika Birleşik Devletleri olduğu gözlemlenir. Şehirleşmeyle birlikte ortaya çıan suç unsurlarının ve güvenliği sağlamak adına alınan önlemler, A.B.D.'de polisiye unsur olarak edebi metinlerde de görülmeye başlanır. Edebiyat araştırmacilarına göre ise polisiyenin tür olarak ele alındığı ilk eser, 1841 yılında Edgar Allan Poe tarafından kaleme alınan ve Graham's Magazine dergisinde yayımlanan 'Morg Sokağı Cinayeti' isimli tefrika romandır (Fişek, 1985, s.4). Poe'nin hikâyesinde başkarakterlerden olan Chevalier Auguste Dupin, aynı zamanda ortaya çıkan ilk dedektif karakter olarak bilinir. Dupin, işlenen iki cinayetin zanlısını ortaya çıkarmayı amaçlayan bir dedektif olarak hikâyedeki yerini alır. Polisiye romanın babası olarak nitelendirilen Edgar Allen Poe'nun yanı sıra Emile Gaboriau, Arthur 
Conan Doyle, Gaston Leroux, Maurice Leblanc gibi yazarlar bu türün diğer kurucuları arasinda bulunur (Gezer, 2006, s.20).

Polisiye romanın Türk edebiyatındaki ilk örnekleri, türün Batı edebiyatındaki ilk örneklerinin verildiği zamandan yaklaşık olarak 40 yıl sonrasına rast gelir. Polisiye romanların Türk edebiyatındaki örneklerinin, ilk olarak çeviri romanlar aracılığıyla sağlandığı bilinir. Türk edebiyatında polisiye türündeki ilk çeviri roman, Fransız yazar Ponson de Terrail' in kaleme aldığı 'Paris Faciaları' isimli eserinin, 1881 yılında Ahmet Münif tarafından Türkçeye kazandırılmasıyla gerçekleşir (Ayata, 2015, s.215). Bu tarihten 2 yıl sonra Ahmet Mithat Efendi tarafından Türk edebiyatının ilk telif polisiye romanı olarak nitelendirilen "Esrar-1 Cinayat" isimli roman yayımlanır (Çetin, 2009, s.230). Buradan hareketle Türk edebiyatında polisiye romanı gelişim açısından ele almak istersek, karşımıza çeviri romanlar ve telif polisiye romanlar olmak üzere iki ana tür çıkar.

Suç ve ceza kavramlarına sinemadaki ontolojik durum açısından bakılırsa yalnızca polisiye türüne ait bir şey olmayıp diğer film türlerinde de görülmesi nedeniyle, eleştirmenler ve akademisyenler bu türün tanımı konusunda ortak bir yargıya varamamışlardır. Polisiye filmin genellikle kara filmler ve gerilim filmleriyle melez bir form oluşturduğunu savunan Sarah Casey Benyahia polisiye filmleri "odak noktasının soruşturma süreci, ipuçlarının çözümü ve gizemin aydınlatılması ya da başka bir biçimde sonuçlandırılmasını" konu edinen bir tür olarak ifade eder (2014, s.14). Nijat Özön ise polisiye filmi “kahramanun, resmi polis yerine özel dedektif olduğu ve kahramanın kendi yöntemlerini kullanarak karanlık bir olayı çözmeye çalıştığı zaman zaman dedektif filmi olarak da adlandırılan film türü" olarak tanımlar (Özön, 2000, s.548-549). Polisiye türü sinema sanatı içerisinde bir tür olarak ele alınmak istendiğinde Polisiye film türünün, Polisiye edebiyatı ile benzer özellikler taşıdığı söylenebilir. Tıpkı edebi türlerdeki gibi Polisiye film türünde de anlatı içerisindeki karakterler sınırlıdır. Filmdeki karakterler tavır, davranış, kıyafet ve hayat tarzlarıyla yaşadıkları dönemin özelliklerini temsil ettikleri gibi aynı zamanda dönemin düşünce yapısını da iletirler. Polisiye film türünde ön plana çıkan en önemli karakterin dedektif olduğu söylenebilir. Dedektif karanlık bir olayı aydınlatmak için ortaya çıkar ve bu olay genel olarak bir kurbanın varlığına bağlıdır. Film içerisindeki suçlular genellikle kurbanlarını önemsiz kişilerden seçerler. Kurbanla ilişkisi olan her karakter sırayla zanlı 
durumuna düşebilir. Dedektif ise kendi beceri ve tecrübeleriyle zanlı listesindeki kişileri en aza indirgeyerek, suçluyu bulmayı hedefler (Roloff, Seeblen, 1997, s.18). Bordwell ve Thompson'a göre (2012, s.332) polisiye filmlerde olay örgüsü daha çok adalet güçlerine yoğunlaştırılır. Bu sayede aksiyon, polisin ya da özel dedektifin suçluyu yakalama veya başka bir suçu önleme durumları gibi bir dizi olay etrafında gerçekleşir. Olay örgüsü polis ya da dedektif takibini ön plana çıkartarak, suçlunun kısa süren bir görünüşünü izleyiciye sunar.

Polisiye filmlere mekânsal kullanım açısından bakılırsa Polisiye hikâyelere benzedikleri söylenebilir. Hikâyelerde görülen sınırlı sayıda mekân kullanımın filmlerde de benzer niteliktedir. "Polis filmleri aynı zamanda kentlerin portreleridirler ve kentler türün metafiziğini oluşturur; polis filmleri kahramanların sahiciliği kadar kentin renkliliğinin canlandırılmasıyla da ilintilidir" (Roloff, Seeblen, 1997, s.324). Film içerisinde oluşturulan kahramanlar ne denli gerçekçi olurlarsa olsunlar olayların geçtiği mekânların, ortaya çıkartılacak olan gerilim ve gizemin oluşmasına zemin hazırlayıcı nitelikte olması oldukça önemlidir. Karanlık ve puslu havalar, kalabalık caddelerin yanında dar ve issız sokaklar polisiye filmlerdeki gizem ve gerilimi destekleyici öğeler olarak sıklıkla görülürler. Polisiye filmlerdeki söz konusu bu atmosferin kurulmasında aydınlatma tasarımının büyük rolü vardır.

\section{Sinemada Aydınlatma Tasarımı}

Sinema içerik ve biçem olmak üzere ikiye ayırabileceğimiz çeşitli öğeler yoluyla anlatısını kurar. Kompozisyon, 1şık, renk gibi görselliğin varoluşunu belirleyen unsurların yanı sıra diyaloglar ve müzik gibi işitsel öğeler ile montaj da eserin bir varlık olarak belirmesini, anlam ve duyguların oluşmasını sağlar (Ulutaş, 2019, s.1016). Aydınlatma, film biçimini oluşturan temel bir öğe olarak anlamın kurulmasında oldukça önemli yer oynar. Sinema sanatının başladığı ilk yıllarda yapılan çekimler dikkate alındığında kullanılan aydınlatma tekniğinin, daha çok nesneleri görünür kılan düz bir aydınlatma tekniği olduğu görülür. Bu çekimlerde gölgelere az rastlanırken genel bir mekân aydınlatmasının oluşturulduğu dikkat çeker. Bu durum Alman dışavurumcu sinemanın ortaya çıkışına kadar devam eder. Alman dışavurumcu sinemayla birlikte gelen teknik yeniliklerin en başında aydınlatmanın psikolojik öğe olarak kullanılması gelir. "Alman dışavurumcu sineması, aydınlatma biçimi ile 
gerçekçiliği etkili bir şekilde bozmayı amaçlamış, bunun için çekimleri dış mekândan stüdyo içine taşımış ve aydınlatma biçimi ile etkili ş̧ık gölge düzenlemeleri geliştirmiştir" (Koca, 2018, s.79). "Bu akım eğik kamera açıları ve gerçeklikten öte, ışık ve gölge kullanımlarıyla anılır (Doğru, 2013, s.69). Dışavurumculuk akımında, gölgelerin yoğun kullanıldığı bir aydınlatma tekniği tercih edilir. Ayrıca gerçek üstü dekorların ve alışılmışın dışında kamera açılarının kullanıldığı da gözlenir.

Sinema sanatında 1şık, hareketin ve aksiyona ait dramatik etkiyi sağlayan temel faktörlerden birisidir. Kameraya kaydedilen görüntünün içindeki aydınlık ve gölge alanların, çekim içerisinde oluşturulan kompozisyonun oluşturulmasına öncülük eder ve izleyicinin tüm algısını izlediği görüntüde toplamasına neden olur. Parlak bir şekilde aydınlatılmış olan bir nesne izleyicinin algısını tamamen oraya çekebileceği gibi; daha az aydınlatılmış alanlarda kalan bir ayrıntı gölge yardımıyla gizlenebilir ya da izleyicide konuya bağlı olarak psikolojik açıdan bir gerilim oluşturabilir. Ayrıca aydınlatma yapılan alanlardaki dokular da ışık yardımıyla ortaya çıkartılmış olur (Bordwell, Thompson, 2012, s.131). Konuların ya da objelerin üzerine düşen ışı̆̆ın miktarının, o konu veya objelerin uzayda kapladığı hacmi ortaya çıkarmasının yanı sıra düşen ışığın miktarının az ya da çok olması, ortaya çıkabilecek dramatik anlamın kurulmasında da etkilidir. Konu ya da obje üzerine düşen ışık miktarının yüksek değerlere sahip olması sonucunda konu veya obje algısal izlenimi kendi üzerine çekecektir. Işık miktarının düşük değerlerde olduğu aydınlatmalarda ise objeler üzerinde gölge bölümlerin oluşmasıyla objelerin ayrıntıları ve dokuları belirsizleşecek; çerçeve içerisindeki derinlik algısı da güçlenecektir. Oluşturulacak olan bu ışık miktarlarındaki yoğunluk derecesi, filmsel zaman algısının oluşması ve filme ait atmosferin tasarlanmasında oldukça etkilidir. Işık yoğunluğundaki oran düştükçe sahnelenen konunun ya da objelerin tanınması güçleşeceğinden dolayı izleyici kendisini gizemli ve tedirgin bir durumun içerisinde bulabilecektir. Gölge alanların oluşturulmasıyla detaylar ve ayrıntılar gizlenecek seyircinin algısı aydınlık kısımlara doğru ilerleyecektir.

Aydınlatmayla sağlanan sinematografik anlatımdaki en temel 1şık tasarımı, üç nokta aydınlatma tekniğidir. Üç nokta aydınlatma tekniği; anahtar 1şık, dolgu 1şık ve kontur 1şık olmak üzere bu üç temel ışığın kurulumuyla sağlanır. Anahtar ışık genellikle pozlamayı belirleyen ışık olarak nitelendiril- 
mekle birlikte konu ya da nesnenin dokusunu ve yüzey yapısını ortaya çıartan 1şık olarak bilinmektedir. Sert bir 1şık kaynağından oluşan anahtar 1şık, aydınlatılan ortamdaki temel gölgeleri oluşturmasının yanı sıra ışığın yönünü değiştirmesiyle de dikkat çeker. Üंç nokta aydınlatmasının bir diğer öğesi dolgu ışığı ise yumuşatıcı bir etkiye sahiptir. Dolgu ışık genel itibariyle anahtar ışığın meydana getirmiş olduğu gölgeleri yumuşatma amaciyla kullanılır. Sahnede gölge alanların aydınlatılmasıyla ışık ve gölge arasındaki geçişlerin yumuşatılır ve ortamda ki genel ton kontrastı da bu şekilde dengelenir. Üçüncü öğe olan kontur ışık kullanılmasıyla beraber aydınlatılan konu ya da nesnenin, arka plandan ayrılarak derinlik kazanması sağlanır. Kontur ışık, konu ya da nesnenin arka kısmını aydınlatır. Kontur aydınlatmayla birlikte nesne ya da konunun arkasında oluşacak ayrıntılar sayesinde, konunun dış çizgileri ortaya çıarak nesnenin biçimi vurgulanmış olacaktır (Millerson, 2007, s.76-77).

Üç nokta aydınlatmasıyla oluşturulan aydınlatma tekniklerinin, taşıdıkları niteliklere göre farklı anlamla ifade ettikleri öne sürülür. Anahtar ışığın aydınlatmadığı bölgelerdeki gölgelerin dolgu ışıklarla aydınlatılması, güçlü ışıklandırma olarak nitelendirilir. Bu aydınlatmada ışı̆̆ın bir tasarım aracı olmasından daha çok gösterge aracı olarak kullanıldığı ifade edilir. Aydınlatılan mekândaki bütün ayrıntıların aynı oranda 1şıklandırıldığı bu ışık tasarımının, müzikaller ve komedi türündeki filmlerde kullanıldığı görülür. Güçlü aydınlatma ile yapılan ışıklandırmalarda gölgelerin varlığının en aza indirgenmesiyle belirtilen tarzdaki filmlerin anlatımına katkı sağlandığı ve o türe ait ışık kullanımına işaret ettiği görülür. Sahne içerisinde görülen her yerin eşit oranda aydınlatılmasıyla birlikte izleyicide güven duygusunun arttığı ve bu nedenle seyircide rahatlama hissinin ortaya çıkması hedeflenir. Gölgeli ya da aydınlık karanlık alanların fazla bırakıldığı aydınlatma tekniğinde ise insanların hayal gücünün negatif yönde etkilemek ve insanların şüpheci bir ruh haline büründürmek hedeflenir. Düşük ışık şiddetiyle kullanılan anahtar ışık, sahnedeki gerilimi oluşturmak ve gizemi destelemek amaciyla dramatik anlatımı desteklemek amacıyla kullanılır. Düşük anahtar ışık; polisiye, kara film, korku, gerilim gibi film türlerinde dramatik anlatımı desteklemek amacryla yaygin olarak tercih edilir (Alton, 1997, s.34-45).

Aydınlatılan ortamdaki ışık miktarlarının yüksek veya düşüklüğü, kayıt altına alınan görüntüdeki kontrastlığın niteliğine de etki eder. "Kontrast çerçevedeki en karanlık ve en aydınlık alanlar arasındaki farklılık derecesine 
gönderme yapar. Yüksek kontrastlı bir görüntü beyaz parlak noktaları, tamamen karanlık alanları ve bunlar arasındaki grilerin dar bir alanını gösterir. Düşük kontrastlı görüntü ise tamamen griler alanına sahiptir" (Bordwell, Thompson, 2012, s.167). Yüksek kontrastlı bir aydınlatmaya sahip görüntünün derinlik algısının daha gelişmiştir. Yüksek kontrastlı aydınlatmayla sağlanmış görüntüdeki, aydınlık ve karanlık alanların ortaya çıkarmış olduğu zıtlığın 3. boyutun oluşmasında etkili olduğu ifade edilir. Gölge oluşumunun fazla olduğu yerlerde derinlik algısının desteklendiği; yüksek kontrastla birlikte konu ya da objelerin dış yüzeylerindeki ayrıntıların ve dokuların ortaya çıkarıldığı görülür. Düşük kontrastlı aydınlatmanın kullanıldığı görüntülerde ise aydınlık-karanlık alanlar arasındaki sert gölge geçişlerinin yerini daha hafif ve keskin sınırların olmadığı bir aydınlatmaya bıraktığı gözlemlenir. Görüntünün her bölgesinin aynı oranda aydınlatılması ve gölgelerin yumuşak bir geçişle sağlanması nedeniyle düşük kontrastlı aydınlatmalar, daha çok sakinleştirici ve durağan bir ortamın oluşturulmasında tercih edilir (Koca, 2011, s.82).

Aydınlatma unsurlarıyla ortaya çıkn bir diğer özelliğin ise aydınlatılan obje ya da nesnelerdeki yüzeyin dokusu olduğu ifade edilir. Objelerin kendilerine özgü yapısal özellikler taşıyan yüzeyleri o objelerin dokusu olarak tanımlanır. Bir çam ağacının gövdesi ya da sıva yapılmış kuru bir duvarda var olan pürüzlü ve girintili-çıkıntılı yüzeyler, bu nesnelerin dokusunu oluşturur. Işığı̆n, nesnenin üzerine düşme yönüne göre dokular daha belirgin hale gelir. Tam karşı cepheden gelen ışık bir objenin dokusunu ortaya çkarma konusunda zayıf kalacaktır. Ancak objenin üzerine düşen ışığın, tam karşı cephe açı yerine farklı derecelerle yanal açılardan verilmesiyle yüzey üzerindeki dokuların, daha belirgin bir hal alacağı aşikardır. "Işık ne kadar yandan gelirse o kadar gölge oluşturmakta, böylece doku da o kadar çok ortaya çımaktadır" (Brown, 2010, s.38). Sert bir ışıkla yapılan aydınlatmalarda yüzeylerin üzerindeki dokular yumuşak ışıkla yapılmış aydınlatmalara göre daha çok ortaya çıar. Sert 1şık, bir taraftan dokunun ortaya çıarak görünmesine imkân sağlarken diğer taraftan aydınlatılan nesnenin yüzeyinin çok girintili ve çıkıntılı olması durumlarında, nesnenin yapısının bozulmasına sebep olabilir. Yumuşak ışık kullanımıyla girintili olan bölgelerdeki doku kayıpları en aza indirgenerek, ağacın dokusu tam olarak ortaya çıkartılabilecektir (Millerson, 2007, s.63). 
Aydınlatmanın dramatik bir unsur olarak kullanılmasının, ışığın nesnel ve öznel olarak bilinen iki çeşit etkisinden kaynaklandığı ifade edilir. Işıkla ortaya çıkartılan nesnel etkinin, aydınlatılan konudaki görünüş farklılıklarının ortaya çkmasıyla sağlandığı görülmektedir. Aydınlatılan konu ya da obje, ışığın geliş yönü ve şiddetine göre farklı görünümlere sahip olabilmektedir. Öznel etki ise; yapılan aydınlatmanın izleyici üzerinde bıraktı̆̆ı kişisel ve duygusal etki olarak dikkat çekmektedir. Gün ışığı veya homojen olarak dağılan bir aydınlatmada izleyici, tamamen kendisini psikolojik açıdan rahat ve güvende hissedebilecekken; ay ışı̆̆ıyla veya sert gölge geçişleriyle oluşturulmuş bir aydınlatmada izleyici kendisini güvensiz ve tedirgin hissedebilmektedir. "Aydınlık, açık, güneşli hava insan üzerinde sevinç, canlılık, yaşama isteği gibi etkiler uyandırabilirken; karanlık, kapalı, yağmurlu hava bunun tam tersine kederli, üzüntülü, boğucu, bunaltıcı duygular uyandırabilmektedir" (Özön, 1999, s.96-97).

Aydınlatmanın dramatik bir öğe olarak kullanımı yaygınlaşmaya başladıktan sonra, sinemada tür filmlerinin de kendilerine özgü aydınlatma tarzlarıyla anıldığı görülmektedir. Korku, gerilim, polisiye gibi film türlerinde daha çok karanlık, loş ve gölgeli aydınlatma tarzları dikkat çekmektedir. Bilimkurgu türünde beyaz, gri ve parlak ışıkların daha çok tercih edildiği görülmektedir. Western film türünün sarı tonlarında ve gün ışığı aydınlatmasıyla anıldığı, psikolojik ağırlıklı filmlerin ise kişinin psikolojisini yansıtan aydınlatmaya göre şekil aldığı belirtilmektedir (Arslantepe, 2012, s.34). Aydınlatma, sinema yapımlarında var olan duyguya güç katmak ve anlatımı desteklemek adına, ışılandırmaya ayrı bir önem atfeder.

\section{Türk Polisiye Sinemasında Aydınlatma Tasarımının 'Av Mevsimi' Filmi Üzerinden Analizi}

\section{Yöntem}

Araştırmanın yöntemi olarak nitel araştırma yöntemlerinden birisi olan "biçimsel analiz" yöntemi belirlenmiştir. Biçimsel analiz yöntemine ilk olarak, Henrich Wölfflin tarafından 1915 yılında yayımlanan "Sanat Tarihinin Temel Kavramları" isimli kitapta değinilmiştir. O dönem içerisinde sanat eserlerinin sahipleriyle birlikte değerlendirildiği ve sanatçların kişisel özellikleri, içinde bulunduğu dönem, almış olduğu eğitim ve yetişmiş olduğu kültür ortamı 
gibi özelliklerin eserlerin incelenmesinde göz önünde bulundurulduğu belirtilmektedir. Wölfflin, sanatın bir kültür ve fikir ürünü olduğundan bahsetmekte ve sanatın kendine has özelliklerinin var olduğunu belirtmektedir. Henrich Wölfflin, büyük sanatçların, her dönemde dünyaya farklı bir gözle baktıklarını; gördüklerini ve hissettiklerini de anlatabilmeleri adına başka formlar oluşturmak zorunda kaldıklarını düşünmektedir. Sanat Tarihinin Temel Kavramları kitabının yayımlanmasıyla birlikte "o zamana kadar herkesçe kabul edilen 'insanı tanı sanatını anla' ilkesi altüst olmuş; araştırmanın yönü sanat yapıtının içeriğinden form yüzeyine kaymış ve form yapısıyla sorunlar çözülmeye çalışılmıştır" (Wölflinn, 1995, s.5).

Biçimsel analiz yöntemi, ilk olarak resim sanatı içerisinde ortaya çıkartılan eserlerin incelenmesi hususunda tercih edilmiştir. Rönesans ve Barok dönem eserlerinin incelenmesi amaciyla tercih edilen biçimsel analiz yönteminin, Henrich Wölflinn tarafından oluşturulan 5 ilkeye dayandırıldığı gözlemlenmektedir. Bu ilkelerin; çizgisel-gölgesel, düzlem-derinlik, kapalı form-açık form, çokluk-birlik, belirlilik-belirsizlik ikilemlerinden oluştuğu görülmektedir. Bu ilkelerin, bazı eserlere tam olarak uygulanabildiği belirtilirken bazı eserlere ise birkaç ilkenin uygulanabildiği ifade edilmektedir.

\section{Av Mevsimi: Filmin Künyesi ve Filme Ait Genel Bilgiler}

Yönetmen: Yavuz Turgul

Senaryo: Yavuz Turgul

Sanat Yönetmeni: Sirma Bradley

Yapımcı: Murat Akdilek, Jeffi Medina

Oyuncular: Şener Şen, Cem Yılmaz, Çetin Tekindor, Melise Sözen, Okan Yalabık, Rıza Kocaoğlu

Müzik: Tamer Çınay

Görüntü Yönetmeni: Uğur İşbak

Kurgu: İsmail Canlısoy

Işık Şefi: Kadir Yazıcı

Tür: Polisiye

Yapım Tarihi: 2010

Gösterim Tarihi: 3 Aralık 2010

Süre: 145 dakika 
Avcı lakaplı Ferman (Şener Şen) karakteri, İstanbul Emniyet Müdürlüğüne bağlı cinayet masasında görevli, emeklilik zamanı gelmiş işinde oldukça tecrübeli bir polistir. Deli lakaplı İdris (Cem Yılmaz) ise Ferman'ın yıllardır yardımcılığını yapmaktadır. Daha sonra bu ikiliye, üniversitenin Antropoloji bölümünden mezun ve iş bulamadığı için polislik mesleğini seçen çömez lakaplı Hasan (Okan Yalabık) dahil olmaktadır. Herhangi bir iş gününde her şey normal seyrinde ilerlerken bir ihbar gelir ve ormanda kesilmiş bir elin bulunduğu bilgisi verilir. İlerleyen zamanlarda bahsi geçen bu üç kişi, ormandaki kesik elin sahibi olan kişiyi bulmaya çalışarak cinayeti aydınlatmaya çalışırlar. Cinayeti aydınlatma sırasında ise bu üç kişinin hayatları belirli noktalarda değişmeye başlar. Ormanda kesik bir şekilde bulunan elin, adli tıp ortamında alınan parmak izinden Pamuk isminde 16 yaşında bir kıza ait olduğu tespit edilir. Araştırmalarına başlayan üç kişi topladıkları deliller sayesinde, Pamuk'un eski sevgilisi Asit Ömer'e (Rıza Kocaoğlu) ulaşır. Asit Ömer'in tercih etmiş olduğu yaşam biçimi ve sevgili oldukları zamanda Pamuk'a uygulamış olduğu şiddet, Asit Ömer hakkındaki iddiaları da güçlendirir.

Filmde ilk olarak bahsi geçen 3 kişinin de film içerisinde zaman zaman özel hayatlarıyla ilgili bilgiler verilir. Yan hikayeler olarak karşımıza çıkan bu bilgilere göre Ferman'ın karısı böbrek yetmezliği hastalığına yakalanmış, hastalıkla mücadele eden bir kişidir. Geçmiş zamanlarda iyileşmesi için bulunan bir böbreği kendinden daha genç yaşta olan bir kıza vererek onun iyileşmesine olanak sağlamıştır. Böbreğini bağışladığı bu kız ise ona karşı minnet borcunu ödemek amaciyla bakımına yardımcı olur. İdris ise filmde karısı olarak karşılaşılan Asiye'den ayrılmış, çocuklarının velayetini üstlenmiş ve annesiyle birlikte yaşayan birisi olarak karşımıza çıkar. Boşandığı halde karısını hala çok seven İdris, kıskançlık krizlerine girerek eski karısı ve yakınındakileri sıklıkla rahatsız eder. Çömez polis olarak karşılaşılan Hasan ise kız arkadaşıyla birlikte geleceğe dair evlilik adına planlar yapar.

Avcı lakaplı Ferman, geçmiş yılların getirmiş olduğu deneyimlerine güvenerek, cinayetin Asit tarafından işlenmediğini düşünür. Ferman işin daha da fazla peşine düşer ve edindiği bilgiler sonucunda cinayete kurban giden Pamuk'un, Türkiye'nin zengin iş adamlarından biri olarak nitelendirilen Battal Çolakzade ile evli olduğunu öğrenir. Battal ve Pamuk arasındaki yaş farkının fazla olması ve Pamuk'un tercih etmiş olduğu yaşam biçiminin farklı olması sebebiyle Ferman bu evliliğin arkasında yatan gerçekleri araştırmaya 
koyulur. Battal'ın ise böbrek yetmezliği hastalığına yakalanan bir kızı vardır. Evin bir odasında tıbbı malzemelerle birlikte bakılan kıza bir çok nakil gerçekleşmesine rağmen başarılı olunamamıştır. Kızını iyileştirme pahasına gözü dönen Battal, karmaşık bir plan yaparak Pamuk'la evlenmiş ve evlendikten sonra da onun böbreğini almıştır. Ancak bu durumu ispat etmek göründüğü kadar kolay değildir. Pamuk'un ailesi ise Battal'a karşı geçmiş yıllardan gelen bir minnet borcu hissederler.

Hikayenin ilerleyen bölümlerinde, içinde bulunduğu durumlarından etkisinden kurutulamayan Hasan, kayınpederi olacağını düşündüğü adamın iş teklifini kabul etmeyi ve mesleği bırakmayı düşünür. Asiye'nin, İdris'in yüzüne acı gerçekleri söylemesi ise İdris'i tamamen yoldan çıkarır. İdris, bu sinirle Battal'ı itiraf ettirmeyi düşünerek, onun evine gizlice girer. Uzun uğraşlar ve zorbalık sonucunda Battal'ı konuşturmayı başaran İdris'i, Battal'ın koruması farketmiş ve silahı ona doğrultması sonrasında İdris'i öldürür. Cinayetin nedenini öğrenen İdris, ölmeden önce Battal'ın ofisindeki kameralara cinayet hakkında bir mesaj bırakır. Olayın çıkmaza girdiği düşünülürken güvenlik kameralarını kontrol eden Ferman, İdris'in bırakmış olduğı gizli mesajı öğrenerek sonrasında olayı çözmeye başlar. Olayların sonunda ise hikaye, başladığı yerde son bulur. Battal Çolakzade olayların başladığı yerde hayatına son verir.

\section{Giriş Sekansı Analizi}
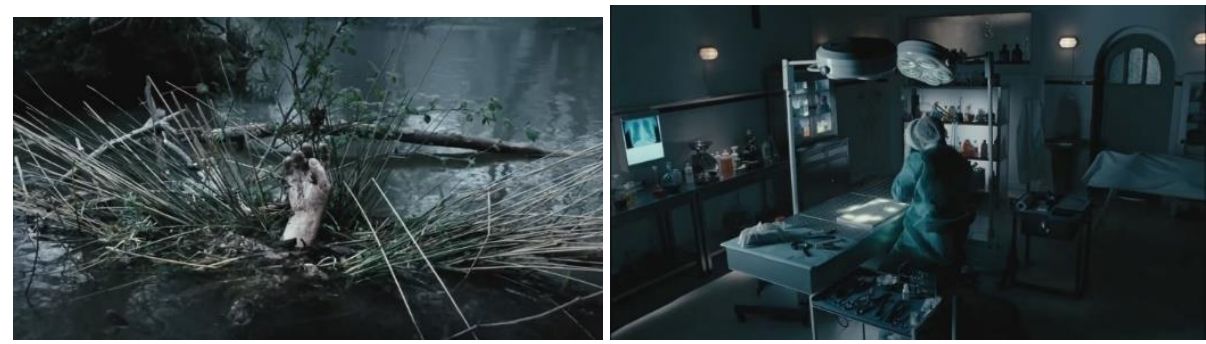

Görsel 1 ve 2. Av Mevsimi Açılış Sahnesinden Kareler (Av Mevsimi, 2010)

Filmin giriş sahnesindeki bu yakın plan çekimin (Görsel 1) aydınlatma tasarımında doğal ışık kullanımı tercih edilmiştir. Çekimin en önemli unsuru olan, olayların başlangıc niteliğinde sayılan kesik el, kompozisyon bakımın- 
dan merkeze yerleştirilmiş ve muhtemelen reflektör ya da herhangi bir yansıtıcı malzeme yardımıyla izleyici açısından daha dikkat çekici hale getirilmiştir. Sahnelenen ortamın renklerinde soğuk renkler tercih edilmiştir. Olay yerinde sisli ve puslu bir havanın var olması ise olaydaki gizemin artmasına yardımcı olan unsurlar arasında yer alır.

Olaydaki sır perdesinin ilk olarak aralanmaya başlayacağı bir sonraki sahnede (Görsel 2), olayla ilgili unsurların kompozisyon açısından merkeze konumlandırıldığı görülür. Sahnedeki ışık tasarımının da bu duruma yardımcı olduğunu söylemek mümkündür. Bu tasarımda yalnızca dikkat çekilmek istenilen bölümlerin aydınlatıldığı ve geri kalan kısımların kademeli olarak azaltıldığı dikkat çeker. Aydınlatma teknikleri açısından Rembrandt aydınlatma yöntemi içerisine giren bu tasarımda yine atmosfer açısından soğuk bir ortamın oluşturulduğu göze çarpar. Merkeze konumlandırılan konunun aydınlatma tasarımı açısından da en belirgin ve güçlü aydınlatmaya sahip olması dikkatleri oraya çeker ve ana unsur olarak orayı işaret eder. Arka planda görülen, üzerine çarşaf serilmiş vaziyette sedye üzerinde yatan bir ceset ve çerçevenin sol kısmında görülen röntgen filmi, izleyicide genel atmosfere uygun bir anlamın oluşması adına yardımcı unsurlar olarak işlev görğr. Bu yardımcı unsurların aydınlatmasının ise ana unsura göre daha zayıf bir şekilde yapıldı̆̆ı gözlemlenir.

\section{Gelişme Sekansı Analizi}
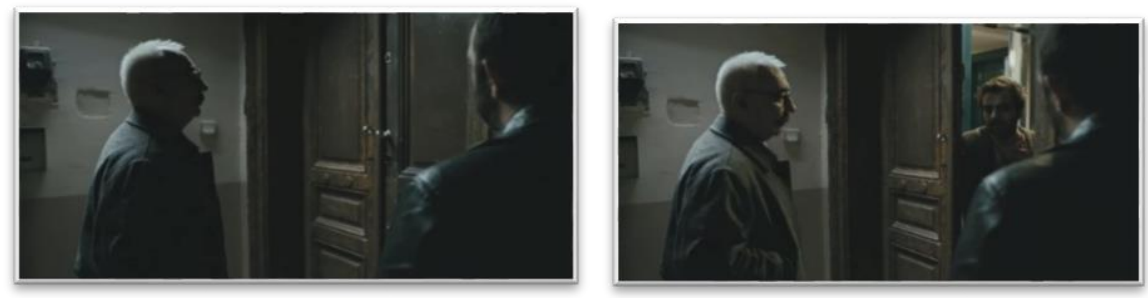

Görsel 3 ve 4. Ferman'ın eve girişi (Av Mevsimi, 2010)

Görsel 3 ve 4'de görünen aydınlatma özelliklerine göre bulunan adreste yer alan eve giden Ferman'a kesik elin sahibi olan Pamuk hakkında önemli bilgiler verecektir. Kapı açılmadan önce siluet bir aydınlatmaya sahip olan Fermanın yüzüne, kapının açılmasıyla birlikte küçük bir ışık düşer. Bu 1şık aynı zamanda Ferman'ın konu hakkında aydınlanmasını sağlayarak cinayet 
hakkındaki bazı sorularına cevap bulacağı anlamına gelir. Ferman, o kapıdan içeri girerek ev sahibinden, Pamuk'un yaşantısı hakkında önemli bilgiler alır.
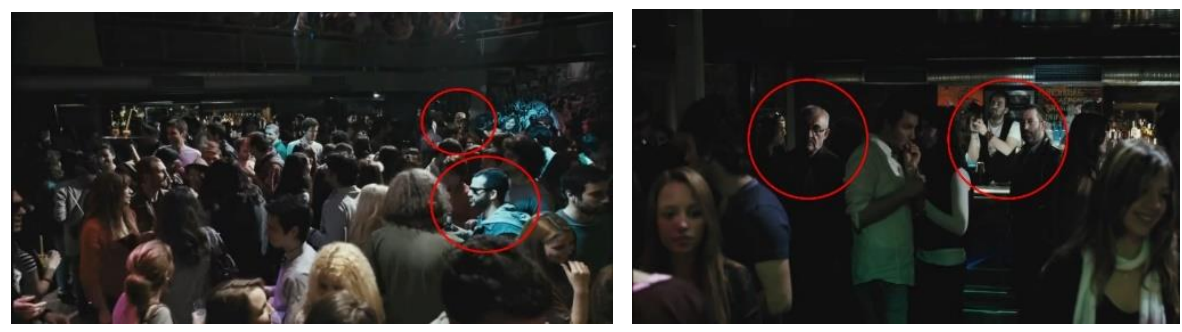

Görsel 5 ve 6. Bar sahnesinden kareler (Av Mevsimi, 2010)

Öykünün gelişme sekansı içerisinde yer alan Bar sahnesinde İdris'e gelen haber sonucu polis ekibi bara giriş yapar. Giriş çekimi olan görsel 5'deki aydınlatma incelendiğinde, tasarım olarak yalnızca konuyu ilgilendiren öğelerin aydınlatıldığı görülür. Görsel 6'da kırmızı halkalar içerisinde gösterilen karakterler, noktasal aydınlatma sayesinde kalabalık içerisinde kolaylıkla anlaş1lırlar. Ön tarafta görülen Asit Ömer ve arka plandaki Ferman karakterleri, yapılan aydınlatma sayesinde kolayca fark edilirler. Görsel 6'da da bir önceki çekime (Görsel 5) benzer bir aydınlatma tercihi görülür. Yapılan tasarımda yine konu açısından önemli olan karakterlerin aydınlatması tercih edilmiş, diğer alanlar kademeli olarak gölge halinde konudan uzaklaştırılmıştır. Önemli kısımlar ön plana çıkartılırken, ayrıntılar göğeler yardımıyla ortadan kaldırılmıştır.
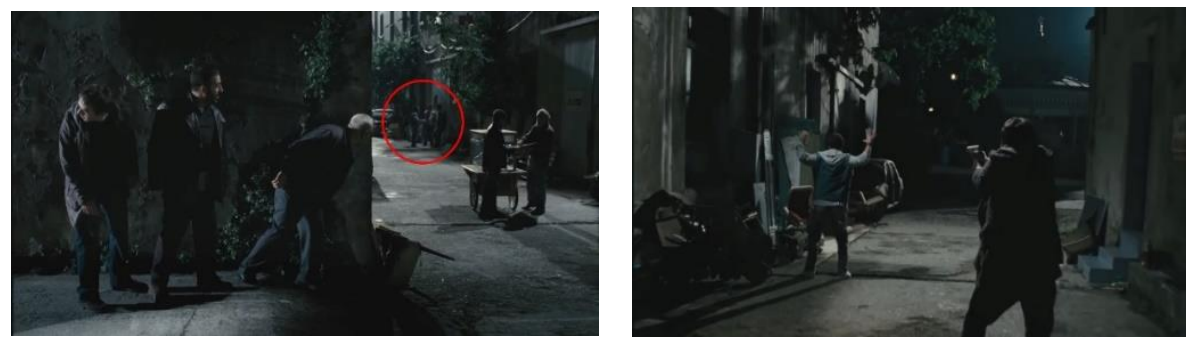

Görsel 7 ve 8. Çatışma sahnesinden kareler (Av Mevsimi, 2010)

İdris, Ömer'i ellerinden kaçırdığını düşünürken Ferman, Avcı lakabının hakkını vererek gözlemleri sonucunda Asit Ömer' in yerini saptar. Var olan 
izleri takip etmeleri sonucunda Ferman ve ekibi, Asit lakaplı Ömer'i bulurlar. Avını izleyen bir avcı gibi hareket eden Ferman'ın canlandırıldığı sahnedeki (Görsel 7) gerilim, Caravaggio' dan sinemaya aktarlan chiaroscuro aydınlatmayla desteklenir. Aydınlatmanın, sert bir nitelikte belirli alanları aydınlatması ve gölge alanların fazla olmasıyla birlikte anlatımın kuvvetlenmesi amaçlanmıştır. Barok dönemi ressamlarında görülen bu aydınlatma yöntemi yalnızca gerekli alanları aydınlatmakta ve ayrıntıları ortadan kaldırmaktadır. Ferman ve ekibinin bölgesi, İdris'in pilav arabasıla birlikte hareket ederek Asit Ömer'in yanına gideceği istikamet ve Asit Ömer'le arkadaşlarının bulunduğu yerlerin aydınlatılması, bu duruma örnek olarak gösterilir. Ömer' in İdris'i fark etmesinin devamında gelişen çekimlerde (Görsel 8) hemen hemen aynı aydınlatma tercihleri dikkati çeker. Aydınlatma gerilimi arttırıcı bir öğe olarak yalnızca istenilen dokuları ön plana çıararak çatışmaya ait tehlike duygusunu destekler. Gölgeli alanların fazla olması yine atmosferin oluşmasına ve görüntünün stilize edilmesine yardımcı olur. Önceki aydınlatma tasarımlarında görüldüğü gibi bahsi geçen çekimlerdeki aydınlatma tasarımlarında da gereksiz yerler gölge alanlarda bırakılarak, izleyicinin algısının aydınlatılmış alanlarda yoğunlaşması sağlanmıştır.

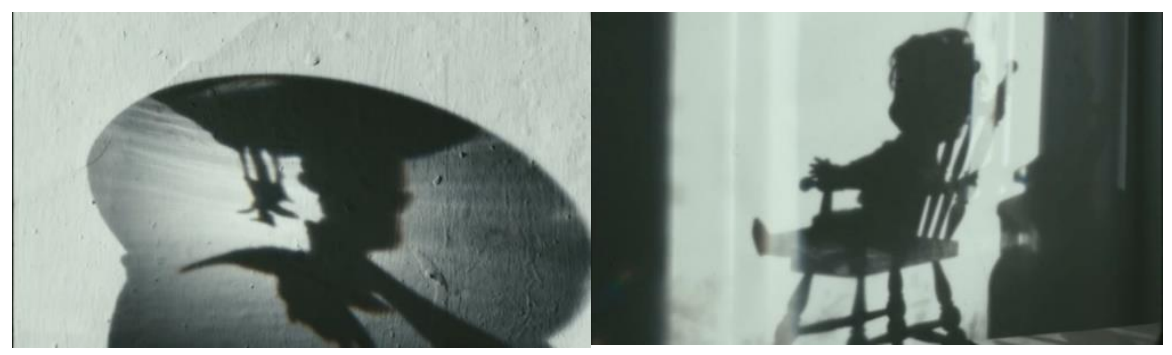

Görsel 9 ve 10. Pamuk'un odası (Av Mevsimi, 2010)

Pamuk'un özel eşyalarının ayrıntılarının yer aldığı çekimlerde (Görsel 910) aydınlatma, var olan nesnelerin görünür hale getirilmesi amacının d1şında kullanılmıştır. Normal şartlarda görüntüde görünen objeler sevimli ve hoş bir şekilde algilanırken, bu çekimlerde tasarlanan aydınlatma sayesinde bahsedilen algıların tersi bir anlam oluşturulur. Güçlü bir ışığın objeleri aydınlatmasiyla duvarda yansıyan gölgeler, bir nevi Pamuk'un acılarla dolu ha- 
yatını sembolize eder. İzleyicide öznel bir etki bırakan bu aydınlatma yöntemi, objelerin görünenden farklı anlamlar taşımasına sebep olmakta ve Pamuk'un geçmişi hakkında farklı düşüncelerin oluşmasına imkân sunar.

\section{Final Sekansı Analizi}
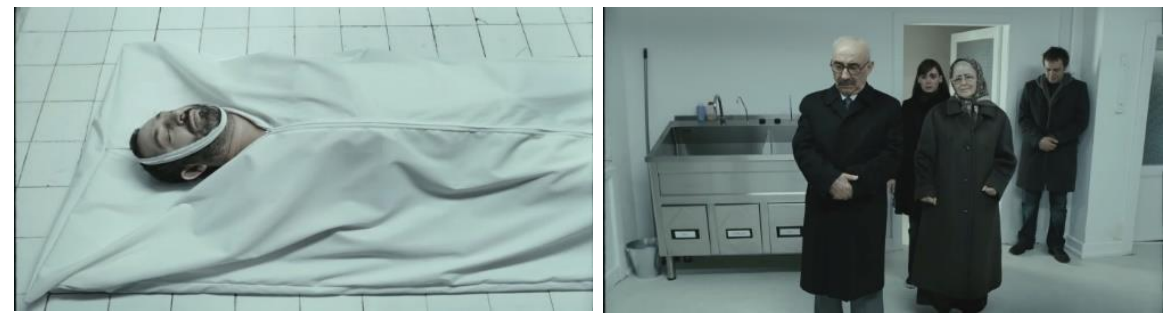

Görsel 11 ve 12. Morg Sahnesi (Av Mevsimi, 2010)

Filmin final sekansı içerisinde İdris'in morga kaldırıldığı çekimde (Görsel 11-12), karakterin ebediyete intikal edişi yoğun, ortamsal, beyaz tonlarda oluşturulan aydınlatma tasarımıyla sağlanır. İdris'ten farklı olarak hayatta kalan insanlar ise beyaz rengin zıttı niteliğindeki siyah renkle temsil edilirler. Ölüm ve yaşamın duygusal anlamdaki zıtlığı aynı zamanda renklerin zıtl-ğıyla da sağlanmıştır. İdris'in cesedinin gösterildiği sahnelerdeki yüksek yoğunluktaki beyaz ışığın bu anlatımı desteklediği söylenebilir.

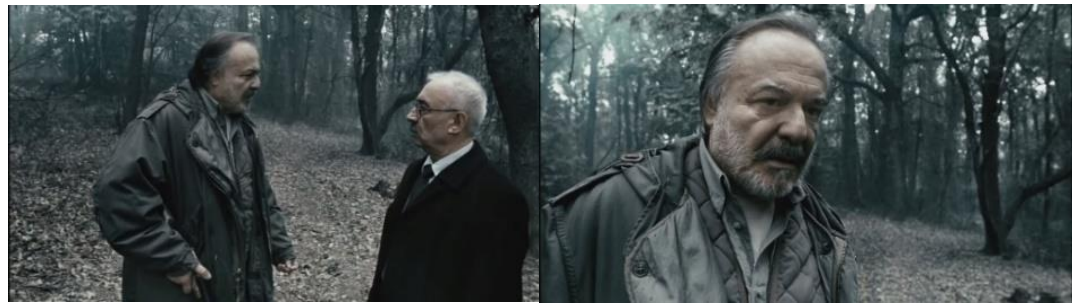

Görsel 13 ve 14. Ferman ve Battal Bey'in karşılaşma sahnesi (Av Mevsimi, 2010)

Ferman, cinayeti çözümlemesinin ardından soluğu Battal Bey'in yanında alır. Uzunca konuşmadan sonra Ferman, cinayeti çözümleme yöntemini Battal Bey'le paylaşır ve onu şaşırtır. Dış ortamda, doğal aydınlatma kaynaklarıyla tasarlanan sahnedeki (Görsel 13-14) 1şığın filmin geneline hitap eden soğuk tonlardan oluştuğu görülür. Filmdeki öykünün Ferman tarafından çö- 
zülmesi neticesinde karakterler arasındakı duygu değişimi ışı̆̆ın yumuşatılması ve farklı nitelikte dağıtıcıların ve yansıtıcıların kullanılarak gölgesel geçişlerle izleyicilere aktarılır. Battal Bey, son olarak cinayeti nasıl ve neden işlediğini açılar ve Ferman'ın ona verdiği tavsiyeyi dinler. Ferman ise bir avcl edasıyla sisli ve puslu havanın içerisinden sessizce uzaklaşır. Doğal aydınlatma tasarımlarının kullanıldığ final çekiminde Ferman, arabasıyla yeni avlarının peşine düşmek üzere olay yerinden uzaklaşır ve film sona erer.

\section{Sonuç}

Barok dönemi ressamlarından Caravaggio ile başlayan ışık ve gölge kullanımı, Rönesans dönemi ressamlarından Rembrandt ile daha da gelişir. Söz konusu ressamların 1şık ve gölge tasarımları yoluyla sahneyi kompoze etmesi resim sanatından başlayarak sinema sanatı içerisinde pek çok yönetmeni ve görüntü yönetmenini derinden etkilemiştir. Aydınlatma tasarımı sinematografik bir öğe olarak oluşturulmak istenen duygusal atmosfere ve görsel dile katkı sunar. Sinemada yer alan pek çok türün kendine ait aydınlatma karakteristikleri bulunur.

Polisiye film türüne özgü olarak gizem, gerilim, aksiyon, tehlikeli hayatlar, güvensiz kişiler, dar sokaklar, cinayet gibi öğeler oluşturulan aydınlatma tasarımlarıyla karakterize edilir.Özellikle Caravvagio'nun eserlerinde görülen aydınlatılan nesne, obje ya da konunun fiziki özelliklerinden daha çok ruhsal ve iç dünyasına dair izlenimleri ortaya çıkartmak isteyen sert ışıklı gölge tasarımları, bu filmlerde kullanılan sıklıkla karşımıza çıkar. Anlatılacak öykü ve verilmek istenen mesajın ön plana çıkartılmak istendiği bu sert ışıklı gölge tasarımlarında ayrıntılar, karanlık alanlarda bırakılarak yok edilir. Bu sayede tasarlanan sahnedeki var olan anlatım ve dikkat, herhangi bir yan olay ya da nesneye takılmadan başarılı bir şekilde aktarılır. Rembrandt'ın eserlerinde işlemiş olduğu ve Caravaggio'ya göre daha yumuşak geçişlerin yaşandığı 1şık gölge tasarımları ise filmlerde görülen diğer bir aydınlatma çeşidi olarak dikkat çeker. Bu aydınlatma tasarımlarının kullanıldığı sahnelerde ise ön plana çıartılan konu, obje ya da nesnelerin görünürlüğüne yardımcı olmak ve onlarla ilgili ayrıntıların fark edilmesini sağlamak amacyyla daha yumuşak gölge geçişleri sağlanır. Dolgu ışık ve farklı yoğunlukta kullanılan 
1şık kaynaklarıyla oluşturulan tasarımda, anlatıma katkıda bulunacak öğelerin ve asıl konu hakkında ek bilgi verecek ayrıntıların fark edilmesi amaçlanir.

Av Mevsimi örneğinde incelenen sahne ve sekanslarda görüldüğü üzere filmdeki genel atmosfer, uygulanan aydınlatma tasarımlarıyla görsel ve duygusal açlardan desteklenir. Filmde tasarlanan aydınlatma öğeleri incelenmek istendiğinde bunu iç mekânlar ve dış mekanlar olmak üzere iki farklı şekilde incelemek daha doğru olacaktır.

Filmde kullanılan iç mekânlar, atmosfer açısından gizemli ve tedirgin bir şekilde izleyiciye sunulurken, çoğunlukla noktasal ışık kaynakları tarafından aydınlatılır. Bu aydınlatma türü Cameo aydınlatma tekniği olarak bilinir. Cameo aydınlatma tekniği, resim sanatı içerisinde Barok dönemi ressamlarından olan Caravaggio'nun eserlerinde sıklıkla kendine yer bulur. Bu aydınlatma tekniğinde, asıl konunun ön plana çıkartıldığı ve diğer ayrıntıların öneminin kaybolmasının istendiği durumlarda tercih edilir. İç mekanlarda, zaman zaman Rembrandt aydınlatma tekniğinin de kullanıldığı görülür. Rembrandt aydınlatma tekniği ise resim sanatı içerisinde Rönesans dönemi sanatçılarından olan ressam Rembrandt'ın eserlerinde kullanmış olduğu bir teknik olarak dikkati çeker. Bu aydınlatma yönteminin ise filmin içerisinde asıl konuya bağlı olan ayrıntıların izleyici tarafından algılanması istendiği durumlarda tercih edildiği görülür.

Filmdeki olayların geçtiği dış mekânlarda ise daha çok doğal aydınlatma kaynaklarının kullanımı gözlenir. Işı̆̆ın ortamda var olan doğal kaynaklar yoluyla tasarlandığı dış mekânlarda, gizemli ve tedirgin atmosferin devam ettirilmesi adına farklı tercihler ön plana çıkar. Ortam ışığının yumuşatıldığ gözlemlenen dış mekânlarda, bazı noktalar gölge alanlar içerisine bilinçli olarak bırakılmıştır. Filmin anlatımına katkı sağlamak amacıyla görüntüde, bilinçli olarak az aydınlatılan ya da karanlıkta bırakılan alanlar yer alır. Bu durumun kompozisyonu sadeleştirmek ve anlatımı kuvvetlendirmek adına büyük etkiye sahip olduğunu söylemek mümkündür. Aynı zamanda diş mekânların geçtiği bazı yerlerde atmosferi daha da etkili kılmak adına yapay sis yardımıyla puslu ve soğuk bir hava görünümü oluşturulmuştur. Sonuç olarak araştırma Av Mevsimi filmi örneği üzerinden, Polisiye türüne ve dünyasına ait olan pek çok karakteristik özelliğin ön plana çıkartılmasında aydınlatma tasarımının oldukça önemli bir işlev gördügünün bir kez daha altını çizmektedir. 


\title{
EXTENDED ABSTRACT
}

\section{Lighting Design in Turkish Detective Films as a Cinematographic Element: An Evaluation on the Example of "Av Mevsimi" Movie}

\author{
Onur Erkan - Murat Aytaş \\ Hacı Bayram Veli University, Selçuk University
}

Establishment of dramatic structure in terms of cinematography or creation of an image in the art of cinema is only possible through the existence of light. The image of film which constitutes the aesthetical dimension of the art of cinema exists through disciplining the light. Light serves not only in the enlightenment of the objects but also in the construction of meaning in the dramatic structure. At this point, lighting techniques are employed not only enlighten the objects but also provide them various meanings and support the existing narration. Cinema has taken over the majority of the techniques related to enlightening from the art of painting. The way which numerous painters such as Caravaggio and Rembrant see and employ the light are also frequently preferred by the directors of photography in the cinema in order to support the meaning and narration. General formulation of visualization of detective stories and supporting narration is achieved through enlightening techniques. Some elements such as mystery, thriller and danger which are often seen in detective stories can be expressed more strongly thanks to lighting techniques in terms of narration.

Dealing with the kind of detective films in accompany with lighting techniques which are cinematographic elements with their characteristic aspects is very important from the perspective of establishing the meaning within this kind. In this research, the camera angles which are frequently employed in the films of detective stories post-2000 Turkish cinema and enlightening techniques which are designed according to those camera angles and the relationship between enlightening techniques and dramatic structures will be analyzed through the sample film of "Hunting Season" (Av Mevsimi) directed by Yavuz Turgul in 2010. Formal analysis method which is employed to 
analyze the works of painting is also employed in the art of cinema in order to examine the images which are reflected onto a two-dimensional plane. In this study, "formal analysis" method which is one of the qualitative research methods was employed as the research method of the film "the Hunting season". The formal analysis method was mentioned for the first time in the book called "The Basic Concepts of Art History" published by Henrich Wölfflin in 1915. It is stated that artworks are assessed in accompany with their producers during that period and the characteristics of the artists, the period in which they exist, their education and the cultural environment in which they are grown are all considered while assessing an artwork. Wölfflin points out that art is a production of culture and idea and art has its own specific characteristics. The formal analysis method was primarily employed in analyzing the artworks which were revealed in the art of painting. It is observed that the formal analysis method which was employed in order to analyze the works of Renaissance and Baroque era is based on 5 principles established by Henrich Wölflinn. Those principles can be listed as lineer-painterly, planerecession, closed form-open form, multiplicity-unity and definiteness-indefiniteness. It has been emphasized that those principles can be fully applied to some of the artworks while only a few of the aforementioned principles can be applied to some other works.

Specific to the detective stories films, the elements such as mystery, thriller, action, dangerous lives, insecure people, narrow streets and murder are characterized through the established lighting designs. As especially seen in the works of Caravvagio, we frequently see the enlightened object or the designs of shadow with harsh light which aims to reveal the impressions related to the spiritual or inner world of the object or the issue instead of its physical characteristics in such films. In those shadow designs with harsh light which aims to reveal the story to tell or the message to give, details are eliminated through leaving them in the dark spaces. By this means, the narration and attention which exist in a designed scene is successively transferred without sticking to any side-events or objects. The light shadow designs which is seen in the works of Rembrandt and in which softer transitions are seen when compared to Caravaggio draw attention as another sort of lighting in the films. In the scenes where such lighting designs are employed, the softer shadow transitions are employed in order to help the visibility of the objects and things which are desired to feature and also help in recognizing the details 
related to them. In the designs which are established through fill-in light and the sources of light employed in various densities, the elements which contribute to the narration and the details which give additional information about the main issue are aimed to bring into forefront.

As seen in the scenes and sequences which were analyzed in the example of "Hunting Season" (Av Mevsimi), the general atmosphere in the film is supported by the applied lighting designs from visual and emotional perspectives. When the lighting elements in the film are analyzed, it will be better to conduct this analysis in two forms such as indoor and outdoor scenes.

The indoor scenes in the film are presented to the audience mysteriously and agitatedly in terms of atmosphere and the scenes are mostly enlightened through point light resources. The aforementioned type of lighting is also known as Cameo lighting technique. The Cameo lighting technique was frequently employed in the art of painting by Caravaggio who is one of the Baroque era painters. In this lighting technique is preferred in the occasions in which actual issue is brought into the forefront and the significance of other details is diminished. In the inner scenes, the Rembrandt lighting technique is also employed from time to time. The Rembrandt lighting technique draws attention since the aforementioned technique was employed in the works of Rembrandt who is one of the artists of Renaissance era. This lighting technique is used in cinema when the details of a film related to the main issue are aimed to present to the audience.

In the outdoor scenes in which the events take place in the film, it is seen that natural lighting resources are preferred. The light was designed through natural resources which exist in the environment related to the outdoor scenes and different choices are made in order to maintain mysterious and unsettled atmosphere. In the outdoor scenes where ambient light is softened, some points are consciously left in the shadowed zone. In order to contribute to the narration of the film, there are some places in the image which are consciously enlightened less or left in shadow. It is possible that this occasion has huge effect to simplify the composition and enhance the narration. In the same time, the image of misty and cold weather was established through the help of artificial fog for some outdoor scenes in order to make the atmosphere more effective. In conclusion, this research points out the functions of lighting design in bringing numerous characteristics of detective stories and detective 
story world into forefront through the example of "The Hunting Season" (Av Mevsimi).

\section{Kaynakça / References}

Alton, J. (1995). Painting with light. University of California Press, London.

Arslantepe, M. (2012). Sinema Okuryazarlı̆̆. Umuttepe Yayınları, Kocaeli

Ayata, Y. (2015). Polisiye roman bağlamında Necip Fazil'ın meşum yakutu, Karadeniz Sosyal Bilimler Dergisi. 7(12), 207-229.

Benyahia, S. C. (2014). Suç. (Çev. A. Birsen). İstanbul. Kolektif Kitap

Bordwell, D. ve Thompson, K. (2012). Film sanatı. (Çevirenler: E. Yılmaz ve E. Suat Onat). Ankara. De Ki Yayınları

Brown, B. (2010). Sinema ve videoda işıklandırma. (Çev. S. Taylaner). İstanbul. Hil Yayınları Çetin, N. (2006). Şiir çözümleme yöntemleri. Ankara. Öncü Kitabevi.

Çetin, N. (2009). Roman çözümleme yöntemleri. Ankara. Öncü Kitabevi.

Doğru, M. S. (2013). Sinema yapımlarında görsel eğretileme ve anlatım aracı olarak işık: Kara Film Örneği. Radyo Televizyon Anabilim dalı. Selçuk Üniversitesi, Sosyal Bilimler Enstitüsü.

Emsley, C. ve Makov, H. S. (2012). Polis dedektifliğinin tarihi. (Çev. A. Handan Konar). İstanbul. Türkiye İş Bankası Kültür Yayınlan

Erkan, O. (2019). Sinematografik bir unsur olarak aydinlatma tekniğinin Türk sinemasi polisiye filmlerinde kullanımı. Radyo Televizyon Anabilim dalı. Selçuk Üniversitesi Sosyal Bilimler Enstitüsü.

Fişek, K. (1985). İyi polisiye iyi edebiyattur. Milliyet Sanat Dergisi. 115(1), 2-5.

Gezer, H. (2006). Türk Edebiyatında Polisiye Roman ve Ahmet Ümit'in Polisiye Roman Kurguları. Türk Dili ve Edebiyatı Anabilim Dalı. Süleyman Demirel Üniversitesi. Sosyal Bilimler Enstitüsü. Isparta.

Holat, O. (2015). Türk sinemasinda polisiye filmlerde değer temsili. Radyo Televizyon ve Sinema Anabilim Dalı. Ege Üniversitesi. Sosyal Bilimler Enstitüsü. İzmir.

Koca, S. (2018). Yeni Türk sinemasinda biçem: anlatınm ve stilistik yapmmn düzenlenmesi. Konya, Literatürk Yayınları.

Millerson, G. (2007). Sinema ve televizyon için aydınlatma tekniği. (Çev. S. Taylaner). İstanbul. Es Yayınları

Ötgün, C. (2008). Sanatın şiddeti ve sinurları. Sanat ve Tasarım Dergisi. 1(1), 90-103.

Özön, N. (2000). Sinema, televizyon, video, bilgisayarl sinema sözlüğü. İstanbul, Kabala Yayınları.

Roloff, B. ve Seeblen, G. (1997). Cinayet sinemasl: Dedektif sinemasinin tarihi ve mitolojisi. (Çev. S. Kaya). İstanbul. Alan Yayıncılık 
Ulutaş, S. (2019). Sinema filmlerinde estetik özneyi yabancılaşmaya yabancllaştırmak: Night Crawler filminde yabancilaştirma etkisi. Selçuk Illetişim, 12 (2) , 1012-1043 .DOI: $10.18094 /$ josc.596288

Wölfflin, H. (1985). Sanat tarihinin temel kavramları. (Çev. H. Örs). İstanbul, Remzi Kitabevi.

\section{Kaynakça Bilgisi / Citation Information}

Erkan, O. ve Aytaş, M. (2020). Sinematografik bir öğe olarak Türk polisiye filmlerinde aydınlatma tasarımı: "Av Mevsimi" filmi örneğinde bir değerlendirme. OPUS-Uluslararası Toplum Araştırmaları Dergisi, 16(31), 4506-4530. DOI: 10.26466/opus.678777 